JKKP: Jurnal Kesejahteraan Keluarga dan Pendidikan

http://doi.org/10.21009/JKKP

DOI: doi.org/10.21009/JKKP.051.03

E-ISSN: 2597-4521

\title{
MODAL SOSIAL, COPING EKONOMI, GEJALA STRES SUAMI DAN KESEJAHTERAAN SUBJEKTIF KELUARGA PADA KELUARGA TKW
}

\author{
Mirdat Silitonga $^{1, \text { a), }}$ Herien Puspitawati ${ }^{2, ~ b), ~}$ Istiqlaliyah Muflikhati $^{1, c)}$ \\ Email : ${ }^{\text {a) mirdatunj@gmail.com, }}{ }^{\text {b) }}$ herien puspitawati@email.com, ${ }^{c)}$ istiqlaliyah@yahoo.com \\ Program Studi Ilmu Keluarga dan Perkembangan Anak \\ Fakultas Ekologi Manusia \\ Pascasarjana Institut Pertanian Bogor \\ Jl. Raya Darmaga, Jawa Barat
}

\begin{abstract}
Kesejahteraan keluarga merupakan sesuatu yang ingin dicapai seluruh keluarga, termasuk keluarga Tenaga Kerja Wanita (TKW), untuk mencapai kesejahteraan tersebut salah satu cara yang dilakukan oleh keluarga TKW adalah mengirim istri sebagai pembantu rumah tangga di berbagai negara. Tujuan dari penelitian ini adalah untuk menganalisis modal sosial, coping ekonomi, gejala stres suami, dan kesejahteraan subjektif keluarga TKW. Penelitian ini menggunakan cross sectional studies. Lokasi dipilih dengan metode purposive di Provinsi Jawa Barat, Kabupaten Cianjur, Kecamatan Tanggeung, Desa Pagermaneuh, Desa Marguluyu, Desa Karangtengah, Desa Tanggeung, Kecamatan Kadupandak, Desa Pasirdalam. Jumlah sampel sebanyak 75 keluarga TKW dengan metode purposive sampling. Penelitian ini menemukan modal sosial berada pada kategori sedang, coping ekonomi berada pada kategori sedang, gelaja stres suami berada pada kategori rendah, dan kesejahteraan subjektif berada pada kategori rendah. Penelitian ini juga menemukan kesejahteraan keluarga berpengaruh terhadap pendapatan perkapita, gelaja stres suami, dan coping ekonomi.
\end{abstract}

Keywords: coping ekonomi, gejala stres, kesejahteraan subjektif, modal sosial.

\section{SOCIAL CAPITAL, ECONOMIC COPING, SYMPTOMS OF HUSBAND'S STRESS AND SUBJECTIVE WELL-BEING OF THE MIGRANT WORKER'S FAMILY}

\begin{abstract}
The achievement of family well - being is an aspiration of all families including families of migrant workers, to achieve the well - being of one of the ways that the families of migrant workers with the departure of the wife work as domestic servants in various countries. The purpose of this study was to analyze social capital, economic coping, sress symptom's husband and family subjektive well - being of women migrant workers. This research use cross sectional studies. The location was chosen purposively in Tanggeung Village, Pagermaneuh Village, Margaluyu Village, Karangtengah Village, Tanggeung District and Pasirdalam Village Kadupandak District, Cianjur, West Java, Indonesia. Seventy five families were selected purposively among the families of women migrant workers. The finding indicates that social capital is in the moderate category, the coping economy is in the moderate category, the sress symptom's husband is in the low category and the family well-being is in the low category. Finding in this study family subjective well-being is influenced by income per capita, sress symptom's husband and economic coping.
\end{abstract}

Keywords: economic coping, family subjective well-being, social capital, stress symptom 


\section{PENDAHULUAN}

Keluarga adalah kelompok kekerabatan terstruktur dengan fungsi pemeliharaan, pengasuhan, dan sosialisasi anak yang baru lahir (Reiss dalam Puspitawati 2013). Keluarga diartikan sebagai sekelompok orang yang diikat oleh pernikahan, darah dan adopsi yang tinggal dalam satu rumah, saling berinteraksi dan berkomunikasi satu dengan yang lain dalam menjalankan peran sosialnya (Burgess \& Locke, 1945). Setiap keluarga pasti memiliki tujuan untuk mensejahterahkan anggota keluarganya. Kesejahteraan merupakan suatu tata nilai kehidupan dan penghidupan bagi setiap individu, keluarga dan masyarakat terhadap berbagai aspek, seperti: ekonomi, sosial, maupun spritual untuk mengadakan usaha-usaha pemenuhan kebutuhan jasmani dan rohani (UUD 1945). Kesejahteraan keluarga adalah istilah ambigu yang dapat merujuk pada kualitas hidup dari unit keluarga tertentu (Families Australia 2006). Kesejahteraan keluarga merupakan suatu kondisi yang diinginkan keluarga di seluruh dunia. Banyak cara yang dilakukan setiap anggota keluarga untuk mencapai kondisi tersebut.

Mencapai tujuan dan kualitas hidup keluarga tersebut, istri dalam keluarga Tenaga Kerja Wanita (TKW) harus meninggalkan keluarga untuk bekerja di luar negeri, hal ini menjadi sebuah dilema, karena dengan perginya istri bekerja keluar negeri menimbulkan berbagai masalah. Puspitawati (2013) menjelaskan benefits dan cost istri bekerja sebagai TKW, adapun benefits istri bekerja sebagai TKW adalah dapat berkontristrisi terhadap kesejahteraan keluarga; merasa diri berguna, mengaktualkan potensi, dan kompetensi diri; dapat berinteraksi dengan orang lain di tempat kerja dan menjadi bagian dari jaringan kerja; menambah wawasan dan pembelajaran hidup, peluang naik haji; memberi contoh pada anak. Sementara cost istri bekerja sebagai TKW adalah harus meninggalkan rumah selama dua tahun; meninggalkan anak untuk dirawat/ dijaga orang lain; ada anak terganggu tumbuh dan kembangnnya; ada resiko suami tidak bahagia/ kawin lagi; rumah kurang terurus; resiko teraniaya; merugi; mati. Berdasarkan data dari BNP2TKI tahun 2012-2015 Provinsi Jawa Barat adalah provinsi dengan jumlah terbesar penyumbang Tenaga Kerja Indonesia (TKI) dan Kabupaten Cianjur sebagai kabupaten nomor tiga terbesar penyumbang TKI, sementara BPS melansir jumlah penduduk miskin di Indonesia pada September 2015 mencapai sebanyak 28.51 juta orang dan Provinsi Jawa Barat menempati urutan pertama dengan jumlah penduduk miskin terbanyak, yaitu 2.7 juta orang, sementara BPS Jawa Barat menempatkan Kabupaten Cianjur peringkat keenam dengan pendapatan perkapita terendah.

Kepergian istri akan memberikan dampak yang lebih serius kepada suami dan anak. Kosongnya peran istri pada keluarga TKW pasti menimbulkan berbagai masalah, seperti: pengelolaan keuangan rumah tangga, kehidupan sosial, pengasuhan, dan dampak fisik dan psikis kepada suami dan anak. Pada keluarga TKW berbagai peran yang harusnya dilakukan oleh istri harus dilakukan oleh suami dan hal ini meyebabkan tekanan psikis pada suami yang dapat menyebabkan gejala stres.

Secara umun terdapat tiga modal yang dimiliki manusia, yaitu modal ekonomi, modal manusia dan modal sosial. Ketiga modal ini yang paling unik adalah modal sosial karena dipengaruhi struktur sosial (Coleman 1988). Coleman mendefinisikan modal sosial berdasarkan fungsinya dan memandang modal sosial bukan entitas tunggal, namun memiliki beragam entitas yang mengandung dua elemen. Pertama modal sosial mencakup beberapa aspek dari struktur sosial, kedua modal sosial memfasilitasi tindakan tertentu dari pelaku (aktor), baik individu maupun komunitas di dalam struktur tersebut. Sama dengan modal lainnya, modal sosial juga bersifat produktif, yakni membuat pencapaian tujuan tertentu yang tidak mungkin diraih bila keberadaan modal sosial tersebut tidak digunakan.

Modal sosial berpengaruh terhadap kesehatan mental, strategi coping, dan kesejahteraan keluarga. Mohnen et al. (2015) menemukan pengaruh modal sosial dan kesehatan individu, semakin baik modal sosial seseorang kesehatannya juga semakin baik, sementara Celia dan Lenora (2004) menemukan adanya pengaruh modal sosial dengan kesejahteraan wanita imigran Somalia yang bekerja di Australia. Wanita imigran Somalia yang baru tinggal di Australia tidak mengenal daerah/

Jurnal Kesejahteraan Keluarga dan Pendidikan (JKKP) Vol.05 No.01 doi.org/10.21009/JKKP.051.03 
lingkungan tempat dia tinggal sehingga mempengaruhi kesejahteraannya. World Bank melaporkan bahwa modal sosial mempunyai kontristrisi dan hubungan positif terhadap peningkatan kesejahteraan rumahtangga (Grootaert 1999). Djohan (2008) menjelaskan bahwa modal sosial merupakan faktor yang sangat berperan penting dalam pembangunan, baik pada level tinggi (negara), level menengah (perusahan) maupun level rendah (keluarga). Hyyppa dan Maki (2003) berpendapat bahwa efek dari modal sosial dapat dinilai pada tingkat individu, bukan masyarakat.

Strategi koping merupakan suatu upaya seseorang untuk menguasai, mengurangi dan menoleransi tuntutan atau masalah yang dihadapi keluarga (Hastuti dan Mulyawati 2009). Keluarga dengan kondisi istri bekerja sebagai TKW jelas memiliki masalah yang dihadapi, karena kekosongan salah satu fungsi strukturnya. Strategi koping dilakukan keluarga untuk menghadapi krisis jangka pendek menuju adaptasi bertahan hidup atau keluar dari kerentanan (Weber 2011). Dalam penelitian ini strategi koping ekonomi yang dilakukan keluarga adalah meminimalisir pengeluaran dan memaksimalkan pendapatan dengan tujuan keluar dari berbagai masalah dan kerentanan.

Coping merupakan suatu proses dimana individu mencoba untuk mengatur kesenjangan persepsi antara tuntutan situasi yang menekan dengan kemampuan mereka dalam memenuhi tuntutan tersebut (Lazarus dan Folkman 1984). Penelitian yang dilakukan oleh Hasanah et al. (2017) menemukan bahwa status ekonomi keluarga berhubungan dengan coping yang dilakukan oleh istri.

Keluarga dengan istri bekerja sebagai TKW pasti membutuhkan banyak coping untuk menghadapi berbagai masalah yang dihadapi. Semakin rendah strategi coping yang digunakan mengindikasikan semakin tinggi kesejahteraan keluarga (Rosidah et al. 2012).

Stres adalah koflik yang berupa tekanan eksternal dan internal serta permasalahan lainnya dalam kehidupan (Haber dan Runyon 1984). Kondisi dengan kosongnya peran istri dalam keluarga TKW memberi peluang yang besar suami mengalami gejala stress, baik dari internal (keluarga) maupun eksternal (lingkungan masyarakat). Glover et al. (2008) menyatakan bahwa modal sosial berpengaruh signifikan terhadap kesehatan mental individu dalam hal ini stres, semakin baik modal sosial individu, maka kecil kemungkinan individu tersebut mengalami stress.

Berbagai masalah yang dihadapi keluarga TKW untuk itu penelitian mengenai modal sosial, strategi coping, gejala stres suami dan kesejahteraan keluarga pada keluarga TKW menarik untuk diteliti. Penelitian ini bertujuan menganalisis modal sosial, strategi koping ekonomi, gejala stres suami dan kesejahteraan keluarga pada keluarga TKW.

Kerangka konseptual yang digunakan dalam penelitian ini adalah Teori Struktural Fungsional. Teori ini menjelaskan bahwa keluarga tidak terlepas dengan struktur, dan dalam struktur tersebut setiap anggotanya mempunyai peran, tugas, tanggung jawab, hak, kewajiban dan fungsi. Teori ini juga disebut dengan teori sistem. Sistem merupakan suatu set objek dan hubungan antar-objek dengan atributnya (Hall dan Fagan dalam Puspitawati, 2012).

Keluarga merupakan unit sosial terkecil di masyarakat yang membentuk sistem. Menurut Churchman (1968) diacu dalam Puspitawati (2013), sistem merupakan bagian-bagian yang bersatu dan terkoordinasi sedemikian rupa sehingga membentuk kesatuan yang utuh dan berupaya mencapai tujuan bersama. Tujuan utama dibentuknya suatu keluarga adalah tercapainya suatu kesejahteraan dan kepuasan hidup. Puspitawati (2013) menyatakan kesatuan dalam keluarga akan mencapai tingkatan maksimum apabila terjadi kinerja maksimum dari komponen-komponen kesatuan keluarga. Pada sistem keluarga komponen tersebut adalah anggota keluarga. Keseimbangan sistem yang didukung keberfungsian peran di dalam struktur keluarga akan memengaruhi tercapainya tujuan keluarga. Kosongnya atau pergi dalam waktu yang cukup lama salah satu anggota keluarga dapat menimbulkan potensi kerentanan keluarga dalam menjalankan fungsinya, seperti keluarga dengan istri bekerja sebagai TKW.

Dalam penelitian Wills $\mathrm{E}$ et al. (2011) tentang hubungan antara persepsi ketidakamanan, modal sosial dengan kesejahteraan subjektif, menemukan bahwa modal sosial berhubungan positif dengan kesejahteraan subjektif, yang berarti semakin baik/ tinggi modal sosial seseorang/ individu maka kesejahteraan subjektifnya juga akan baik/ tinggi. Mohnen et al. (2015) menemukan pengaruh modal sosial dan kesehatan individu, semakin baik modal sosial seseorang kesehatannya juga

Jurnal Kesejahteraan Keluarga dan Pendidikan (JKKP) Vol.05 No.01 doi.org/10.21009/JKKP.051.03 
semakin baik. Celia dan Lenora (2004) menemukan adanya pengaruh modal sosial dengan kesejahteraan wanita imigran Somalia yang bekerja di Australia, dimana wanita imigran Somalia yang baru tinggal di Australia tidak mengenal daerah/ lingkungan tempat dia tinggal sehingga mempengaruhi kesejahteraannya, sementara World Bank melaporkan bahwa modal sosial mempunyai kontristrisi dan pengaruh positif terhadap peningkatan kesejahteraan rumahtangga (Grootaert 1999). Penelitian Alfiasari (2008) menunjukkan bahwa keberadaan modal sosial mempunyai hubungan yang signifikan dengan peningkatan kesejahteraan keluarga miskin. Partisipasi dari anggota keluarga, jaringan sosial dan struktur sosial lainnya berpengaruh signifikan untuk mensejahterahkan seseorang (Kawachi 2006). Hasil Penelitian Fujiwara dan Kawachi (2008) menyatakan bahwa adannya dampak positif dari modal sosial dengan kesehatan mental.

Modal sosial yang baik, akan meningkatkan kesehatan mental, relasi yang positif, mampu menerima dirinya apa adanya, kepribadian yang bertumbuh, tingkat kepercaan tinggi dan merasa nyaman (Markovic dan Manderson, 2002). Hasil Penelitian Garcia dan McDowell (2010) menyatakan semua keluarga dapat mengalami masalah dalam modal sosial (pendapatan yang rendah, masalah hukum, penyakit dan sebagainya), keluarga seperti ini sering disebut dengan keluarga dengan status rendah yang menyebabkan keluarga tidak produktif dalam kehidupan sosial dan hal ini bisa menyebabkan stres anggota keluarga.

Berdasarkan Sustainable Livelihood Approach yang dikembangkan oleh Scoones, keluarga melakukan strategi koping untuk keluar dari kondisi rentan yang mengganggu sumberdaya, salah satunya adalah modal sosial. Strategi coping dipengaruhi oleh modal sosial (Krantz 2001) dan modal sosial dapat membantu rumah tangga dalam upaya strategi koping terhadap resiko pendapatan yang tidak menentu (Grootaert 1999). Semakin sedikitnya strategi coping yang digunakan mengindikasikan semakin meningkatnya kesejahteraan keluarga (Rosidah et al. 2012). Kemiskinan berdampak pada keterbatasan akses yang dapat digunakan keluarga untuk melakukan strategi coping (Hossain 2006). Debebe et al. 2013 menemukan perbedaan coping ekonomi yang dilakukan oleh penduduk afrika dalam menghadapi guncangan ekonomi, coping yang dilakukan penduduk afrika adalah tidak menabung dan mengurangi konsumsi. Borner et al. (2012) menyatakan bahwa coping ekonomi yang dilakukan keluarga tergantung kepada kepemilikikan sumberdaya yang dimiliki, apabila memiliki asset yang banyak, seperti tanah, maka keluarga akan menjual tanah dalam melakukan coping ekonomi

Penelitian Laessle dan Lindel (2010) menyatakan bahwa coping berpengaruh terhadap stress dan depresi. Jordan et al. (2015) menemukan tingginya tingkat stres penduduk jamaika sehingga, penduduk jamaika melakukan koping untuk menghadapi stress tersebut. Penelitian ini juga mengeksplorasi dampak dari psikologi, prilaku dan emosi. Temuanya adalah psikologi, prilaku dan emosi sangat berpengaruh terhadap tingkat stress dan bagaimana proses koping seseorang. Dalam penelitian Bhattacharya (2011) menunjukkan pentingnya modal sosial bagi imigran india yang berada di New York, seperti kedekatan dengan keluarga yang berada di India. Modal sosial juga sangat membantu pemuda India dalam menjalankan fungsi sosialnya di tempat kerja sehingga hal ini semua membantu pemuda India yang berada di Kota New York dalam menghadapi stres budaya. Glover et al. (2008) menyatakan bahwa modal sosial berpengaruh signifikan terhadap kesehatan dalam hal ini stress, penelitian ini juga menemukan perempuan lebih baik memamfaatkan modal sosial dalam menghadapi stress.

\section{METODE PENELITIAN}

Penelitian ini akan menggunakan Cross Sectional Study, yaitu penelitian yang dilakukan hanya pada waktu tertentu dan tidak berkelanjutan. Pemilihan lokasi dilakukan secara purposive di Kecamatan Tanggeung, Kabupaten Cianjur Selatan, Jawa Barat dengan pertimbangan bahwa Kabupaten Cianjur menduduki peringkat ke 3 terbesar sebagai penyumbang TKI di Jawa Barat dan ke 6 terbesar dari seluruh Indonesia. Penelitian akan dilaksanakan pada bulan November sampai bulan Desember 2016. Populasi dalam penelitian ini adalah suami yang tinggal di Kecamatan Tanggeung, Kabupaten Cianjur Selatan. Contoh penelitian ini adalah suami. Penentuan contoh

Jurnal Kesejahteraan Keluarga dan Pendidikan (JKKP) Vol.05 No.01 doi.org/10.21009/JKKP.051.03 
dilakukan secara purposive sampling dengan kriteria istri bekerja sebagai TKW minimal enam bulan. Jumlah contoh sebanyak 100 suami. Responden penelitian adalah suami.

Data yang dikumpulkan melalui wawancara, kemudian diolah dan dianalisis melalui Microsoft Excel dan Structural Equation Model (SEM). Proses pengolahan data meliputi editing, coding, entry, scoring, dan analisis. Pengolahan data dilakukan dengan menggunakan analisis deskriptif dan analisis inferensia. Analisis deskriptif digunakan untuk mengidentifikasi rata-rata, standar deviasi, nilai maksimum dan nilai minimum dari karakteristik keluarga (usia suami-istri, usia menikah suami-istri, lama perkenalan dengan pasangan, lama menikah, jumlah anggota keluarga, lama pendidikan suami istri, pekerjaan suami istri, pekerjaan suami-istri, dan pendapatan per kapita), kesiapan menikah, tugas perkembangan keluarga serta kepuasan pernikahan. Analisis inferensia yang digunakan Structural Equation Model (SEM) menggunakan smart Partial Least Square (PLS) Techniques. Analisis smart Partial Least Square (PLS) merupakan metode analisis yang powerful karena dapat diterapkan pada semua skala data dan tidak membutuhkan banyak asumsi. SmartPLS juga digunakan sebagai konfirmasi teori, membangun hubungan yang belum ada landasan teorinya atau pengujian proporsi, dan pemodelan struktur dengan indikator bersifat reflektif ataupun formatif (Jaya dan Sumertajaya 2008).

Menurut Hussein (2015) smartPLS tidak mensyaratkan jumlah minimum sampel yang digunakan maka teknik statistik yang digunakan adalah Partial Least Square Path Modeling. SmartPLS merupakan suatu teknik statistik multivariate yang banyak melakukan perbandingan antara multiple eksogen dan endogen variabel dengan banyak indikator (Jaya dan Sumertajaya 2008).

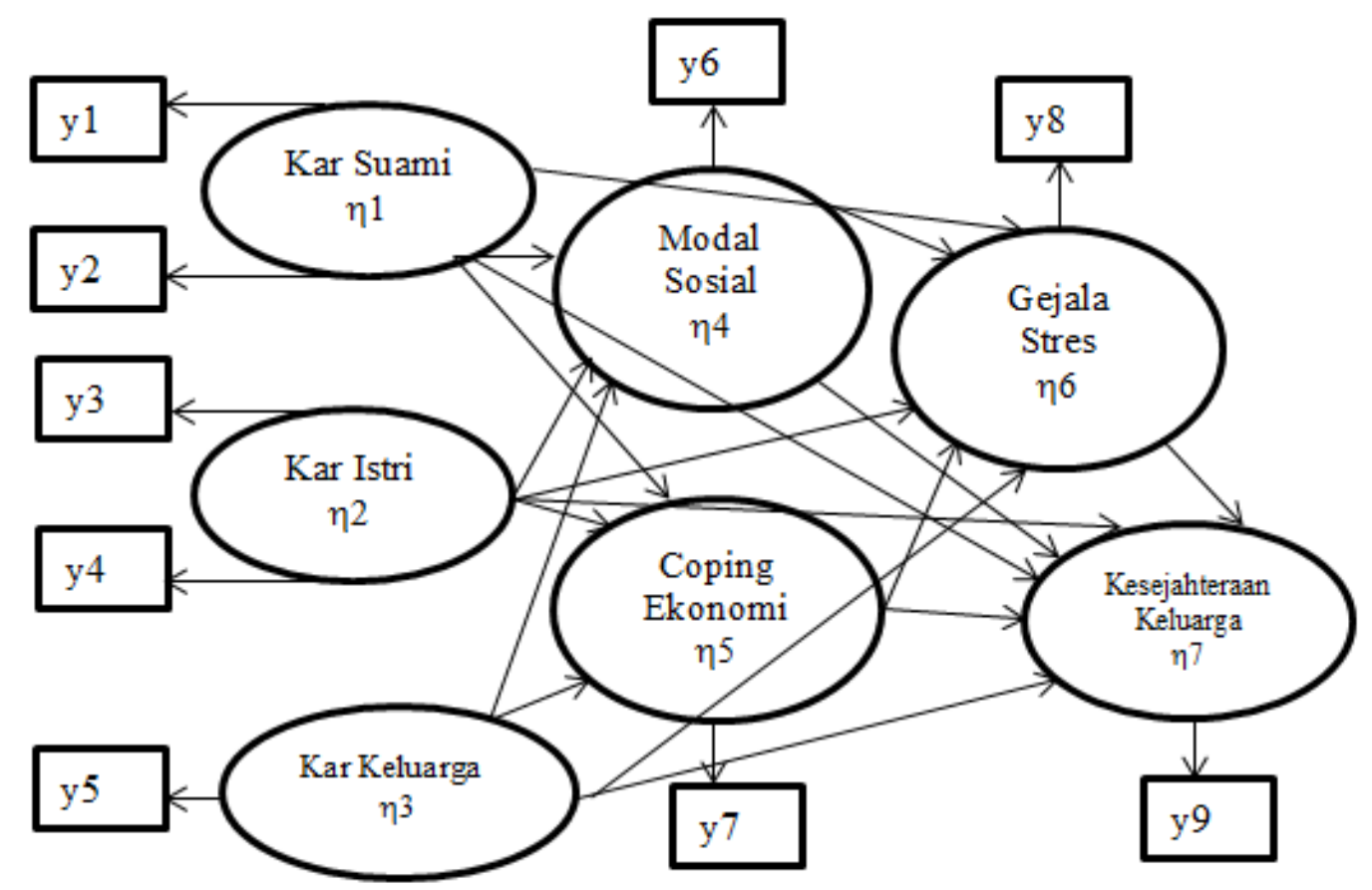

y1: Usia Suami

y2: Pendidikan Suami

y3: Lama Istri TKW

y4: Usia Istri

y5: Pendapatan Perkapita y6: Modal Sosial

y 7: Coping Ekonomi

y8: Gejala Stres Suami

y9: Kesejahteraan Keluarga

\section{Gambar 1. Model Pengukuran Pengaruh Antar Variabel dalam Smart PLS}


Variabel penelitian selanjutnya diberikan skor penilaian pada setiap pertanyaan kuesioner. Variabel modal sosial mempunyai empat dimensi yaitu partisipasi, kepercayaan, hubungan timbal balik, dan norma sosial. Pengukuran dari setiap jawaban menggunakan pilihan "selalu", "sering", "kadang-kadang", dan "tidak pernah" dengan skor (1: Tidak Pernah 2: Kadang-kadang 3: Sering 4: Selalu). Variabel coping ekonomi terdiri dari empat dimensi yaitu pengurangan konsumsi, menambah penghasilan, menjual asset dan mencari bantuan. Pengukuran dari setiap jawaban menggunakan pilihan "selalu", "sering", "kadang-kadang", dan "tidak pernah" dengan skor (1: Tidak Pernah 2: Kadang-kadang 3: Sering 4: Selalu). Variabel gejala stress suami terdiri dari empat dimensi, yakni kognitif, fisik, afektif dan tingkahlaku. Pengukuran dari setiap jawaban menggunakan pilihan "selalu", "sering", "kadang-kadang", dan "tidak pernah" dengan skor (1: Tidak Pernah 2: Kadang-kadang 3: Sering 4: Selalu). Variabel kesejahteraan keluarga terdiri dari empat dimensi, yakni hubungan dalam keluarga, kondisi ekonomi, kesehatan dan agama. Pengukuran dari setiap jawaban menggunakan pilihan "sangat puas", "puas", "kurang puas", dan "tidak puas" dengan skor (1: Tidak puas 2: Kurang puas 3: Puas 4: Sangat puas). Kemudian skor total dari masing-masing variabel ditransformasikan menjadi skor indeks Gambar 1). Hal ini dilakukan agar memperoleh nilai minimum 0 dan nilai maksimum 100. Selain itu, bertujuan untuk menyamakan satuan agar perbandingan pengategorian data setiap variabel seragam (Puspitawati dan Herawati 2013). Indeks dihitung dengan rumus :

Keterangan :

$$
\text { Rumus Indeks }=\frac{\text { Skor aktual-nilai minimum }}{\text { Nilai maksimum-nilai minimum }} \times 100
$$

Indeks : skala nilai 0-100

Nilai aktual : nilai yang diperoleh responden

Nilai maksimal : nilai tertinggi yang seharusnya dapat diperoleh responden

Nilai minimal : nilai terendah yang seharusnya dapat diperoleh responden

Skor indeks yang dicapai dikategorikan berdasarkan rentang kelas. Tiga kategori yang digunakan, yaitu rendah, sedang, dan tinggi. Cut off ini yang digunakan untuk mengkategorikan variabel kesiapan menikah, fungsi keluarga dan pelaksanaan tugas keluarga. Cut off yang digunakan

Rendah $\quad: 0.00-50.00$

Sedang : :50.01-75.00

Tinggi $\quad: \geq 75.01$

\section{HASIL DAN PEMBAHASAN}

Pendapatan suami pada penelitian ini cukup rendah apabila dibandingkan dengan pendapatan istri, terlihat dari kontribusi pada pendapatan keluarga, namun walaupun kecil, pendapan suami berhungan signifikan dengan modal sosial, yang berarti semakin besar pendapatan suami maka modal sosial keluarga akan semakin baik, namun semakin tinggi pendapatan suami. Hal ini sesuai dengan temuan pada penelitian Garcia dan McDowell (2010) bahwa pendapatan suami berhubungan positif dengan modal sosial. Berdasarkan pengamatan, hal ini juga terkonfimasi, bahwa suami yang memiliki pendapatan lebih besar memudahkan dia untuk mengakses kehidupan sosial.

Besar pendapatan suami juga berhubugan positif signifikan dengan kesejahteraan keluarga, temuan ini sesuai dengan penelitian yang dilakukan Carbonell (2005), menemukan bahwa pendapatan berhubungan positif dengan kesejahteraan, semakin besar pendapatan seseorang maka dia akan merasa sejahtera/ puas dalam hidupnya. Penelitian yang dilakukan Helliwell J F et al. (2013) menemukan adanya hubungan positif signifikan antara pendapatan dengan kesejahteraan. Penelitian Diener dan Tay (2013) menemukan adanya hubungan antara pendapatan dengan kesejahteraan subjektive, dimana semakin meningkat pendapatan seseorang akan meningkat juga kesejahteraan orang tersebut. Dalam penelitian ini pendapatan suami berhubungan positif dengan modal sosial dan kesejahteraan keluarga, sementara pendapatan istri yang jauh lebih besar berhubungan negatif walaupun tidak signifikan dengan kesejahteraan keluar, hal ini dikarenakan, kesejahteraan yang diteliti oleh peneliti adalah kesejahteraan subjektif, oleh karena itu walapun pendapatan istri besar,

Jurnal Kesejahteraan Keluarga dan Pendidikan (JKKP) Vol.05 No.01 doi.org/10.21009/JKKP.051.03 
namun banyak suami yang kurang setuju atau setuju dengan terpaksa atas kepergian istri bekeja sebagai TKW.

World Bank melaporkan bahwa modal sosial mempunyai kontribusi dan hubungan positif signifikan dengan peningkatan kesejahteraan rumahtangga (Grootaert 1999). Hal ini sesuai dengan temuan pada penelitian ini, dimana modal sosial berhubungan positif signifikan dengan kesejahteraan keluarga. Artinya semakin baik modal sosial keluarga, maka kesejahteraan keluarga tersebut pasti akan meningkat. Glover et al. (2008) menyatakan bahwa modal sosial berhubungan positif signifikan dengan kesehatan mental individu dalam hal ini stres, semakin baik modal sosial individu, maka kecil kemungkinan individu tersebut mengalami stress. Penelitian Eduardo Wills et al., (2011) menemukan adanya hubungan persepsi terhadap ketidaknyamanan dan modal sosial terhadap kesejahteraan subjektif, semakin tinggi persepsi seseorang terhadap rasa ketidaknyaman maka kesejahteraan subjektifnya semakin rendah, sedangkan semakin baik modal sosial seseorang kesejahteraan subjektifnya juga baik.

Penelitian Alfiasari (2008) menunjukkan bahwa keberadaan modal sosial mempunyai hubungan yang signifikan dengan peningkatan kesejahteraan keluarga miskin. Partisipasi dari anggota keluarga, jaringan sosial dan struktur sosial lainnya berhubungan signifikan untuk mensejahterahkan seseorang (Kawachi 2006). Penelitian yang dilakukan Helliwell J F et al. (2013) menemukan adanya hubungan modal sosial dengan kesejahteraan, dimana semakin baik modal sosial, maka akan meningkatkan kesejahteraan individu tersebut. Penelitian yang dilakukan Welsh $\mathrm{J}$ A et a.l (2009) bahwa modal sosial berhubungan positif dengan kesehatan dan kesejahteraan, semakin baik modal sosial seseorang maka dia akan semakin sehat dan sejahtera. Penelitian yang dilakukan Yip W et al. (2007) di pedesaan china menemukan adanya hubungan positif antara modal sosial dengan kesejahteraan keluarga.

Coping ekonomi yang dilakukan suami dalam penelitian ini cukup membantu keluarga dalam menghadapi tekanan ekonomi, namun hal ini membuktikan bahwa keluarga TKW semakin kurang sejahtera. Berdarkan hasil uji statistik, ditemukan bahwa adanya hubungan positif signifikan antara coping ekonomi dengan kesejahteraan keluarga, dimana semakin banyak coping ekonomi yang dilakukan oleh keluarga, maka semakin mnegindikasikan rendahnya tingkat kesejahteraan keluarga. Menurut Weber (2011) strategi coping dilakukan keluarga untuk menghadapi krisis jangka pendek menuju adaptasi bertahan hidup atau keluar dari kerentanan. Temuan pada penelitian ini senada dengan penelitian yang dilakukan Rosidah et al. (2012) dimana semakin rendah strategi coping yang digunakan mengindikasikan semakin tinggi kesejahteraan keluarga. Jha $R$ et al. (2012) melakukan penelitian di india, dimana coping dengan cara meminjam dari teman berhubungan negatif signifikan dengan kesejahteraan keluarga, yang berarti semakin banyak meminjam uang mengindikasikan keluarga tersebut kurang sejahtera.

Gejala stres suami pada penelitian ini termasuk rendah, namun pada dimensi fisik cukup tinggi. Pada penelitian ini menemukan adanya hubungan negatif signifikan antara gejala stres suami dengan kesejahteraan keluarga, dimana semakin banyak gejala stres yang dialami keluarga maka kesejahteraan keluarga akan semakin menurun, temuan ini sesuai dengan penelitian yang dilakukan Jain A K et al. (2013) menemukan bahwa apabila seseorang tidak bisa mengorganisir stres akan menyebabkan dia tidak sejahtera. Sedana dengan temuan pada penelitian ini, Rebecca $\mathrm{P}$ et al. (2013) menyatakan, bahwa semakin banyak tekanan ekonomi atau tidak sejahteranya keluarga akan menyebabkan meningkatnya gejala stress, bahkan sampai depresi.

Jurnal Kesejahteraan Keluarga dan Pendidikan (JKKP) Vol.05 No.01 doi.org/10.21009/JKKP.051.03 


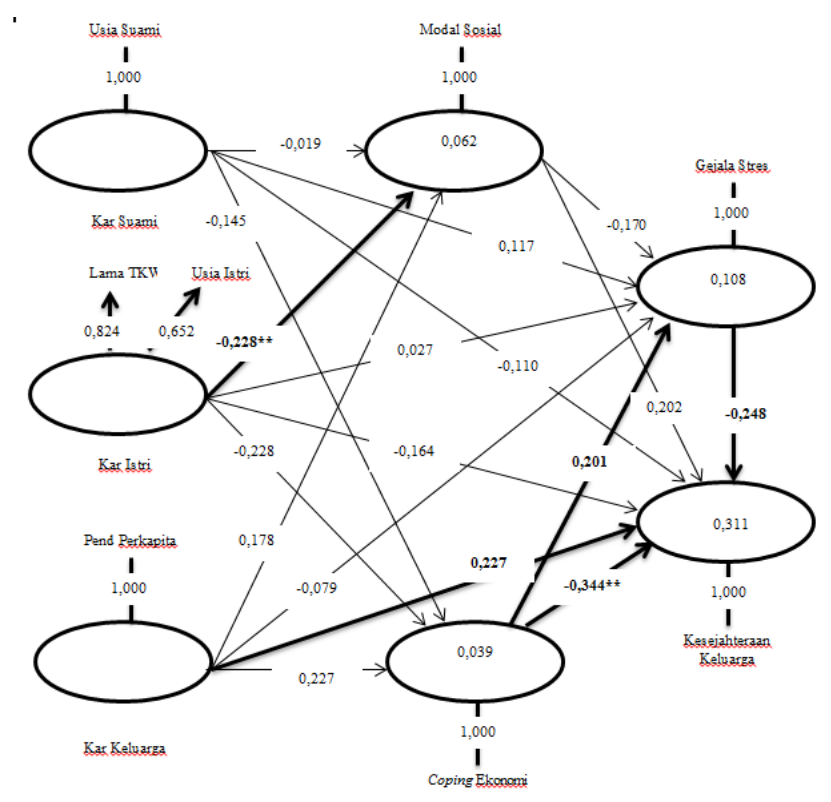

Gambar 2. Hasil Uji Pengaruh Smarts PLS

Penelitian ini menemukan adanya pengaruh positif signifikan antara besar pendapatan keluarga dengan kesejarteraan keluarga (Gambar 2). Artinya semakin besar pendapatan keluarga maka akan meningkatkan kesejahteraan keluarga tersebut. Stevenson B dan Wolfers J (2013) menemukan adanya pengaruh positif antara pendapatan keluarga terhadap kesejahteraan keluarga di Amerika Serikat. Sedana dengan temuan pada penelitian ini, Headey B dan Mark W (2004) menyatakan bahwa pendapatan dari suatu keluarga berpengaruh positif signifikan terhadapap kepuasan hidup keluarga.

Coping ekonomi yang paling banyak dilakukan keluarga adalah coping mengurangi penghasilan, karena cara ini cukup efektif dalam menghadapi tekanan ekonomi, seperti kiriman istri belum dating dan suami belum mendapatkan pekerjaan, karena mayoritas suami bekerja sebagai buruh harian lepas. Penelitian ini menemukan adanya pengaruh positif signifikan coping ekonomi terhadap gejala stress suami. Temuan ini sesuai dengan penelitian Laessle dan Lindel (2010) menyatakan bahwa coping berpengaruh terhadap stress dan depresi. Jordan et al. (2015) menemukan tingginya tingkat stres penduduk jamaika sehingga, penduduk jamaika melakukan coping untuk menghadapi stress tersebut. Saat individu mengalami stres, individu cenderung melakukan strategi dalam menghadapi stress tersebut dengan menghindar/ avoidance terhadap masalah yang dihadapinya dalam hal ini tekanan ekonomi (Dwyer dan Cummings 2001).

Penelitian ini juga menemukan adanya pengaruh negatif signifikan coping ekonomi terhadap kesejahteraan keluarga. Dercon S (2000) menemukan keluarga yang sering melakukan pengurangan konsumsi adalah keluarga dengan penghasilan yang rendah atau keluarga yang kurang sejahtera, dengan kata, seemakin banyak coping ekonomi yang dilakukan keluarga mengindikasikan kesejahteraan keluarga tersebut rendah. Ersado et al. (2014) menyatakan keluarga dengan penghasilan rendah melakukan coping ekonomi dengan mengurangi konsumsi. Debebe et al. (2013) Penelitian di pedessaan Ethiopia ini menunjukkan keluarga akan melakukan coping ekonomi berupa tidak menabung, mengurangi konsumsi, menjua asset, meminjam/ mencari bantuan dan bekerja sebagai pekerja harian lepas apabila terjadi economic shock/ tidak sejahteranya keluarga Berdasarkan Sustainable Livelihood Approach yang dikembangkan oleh Scoones, keluarga melakukan strategi coping untuk keluar dari kondisi rentan yang mengganggu sumberdaya.

Penelitian ini juga menemukan adanya pengaruh signifikan negatif gejala stress suami terhadap kesejahteraan keluarga. Yang artinya semakin meningkat gejala stres suami, hal ni akan menyebabkan menurunnya kesejahteraan keluarga. Berdasarkan penelitian Casey $L$ (2013) gejala stress dapat disebabkan oleh masalah keuangan, masalah dalam keluarga, masalah kesehatan

Jurnal Kesejahteraan Keluarga dan Pendidikan (JKKP) Vol.05 No.01 doi.org/10.21009/JKKP.051.03 
individu, masalah dalam pekerjaan, masalah dengan pasangan dan masalah dengan sahabat/teman. Penelitan ini menemukan bahwa gejala stress berpengaruh negatif terhadap kesejahteraan.

\section{KESIMPULAN}

Suami yang memiliki pendapatan lebih besar cenderung memiliki modal sosial yang lebih baik, dengan memiliki pendapatan yang cukup besar suami dapat mengakses kehidupan sosial. Besarnya pendapatan suami juga memiliki dampak yang besar kepada kesejahteraan keluarga, suami yang memiliki pendapatan yang lebih besar, cenderung merasa lebih sejahtera dari pasa suami yang memiliki pendapatan lebih rendah. Modal sosial yang dimiliki keluarga cukup baik, suami cukup baik dalam berpartisipasi pada kegiatan-kegiatan di lingkungan, hal ini membantu keluarga dalam melakukan coping ekonomi, yakni meminjam/ meminta bantuan dari keluarga besar, teman dan tetangga. Modal sosial juga membantu suami dalam menanggulangi rasa kesepian pasca ditinggal istri, sehingga terhindar dari gejala stres. Keluarga yang memiliki modal sosial yang baik cenderung keluarga yang tingkat kesejahteraannya baik.

Coping ekonomi merupakan suatu cara yang dilakukan keluarga untuk keluar dari tekanan ekonomi, coping yang dilakukan keluarga TKW adalah dengan cara meminjam uang, mencari pekerjaan tambahan dan mengurangi konsumsi, sementara coping menjual asset tidak dilakukan karena keterbatasan asset yang dimiliki keluarga TKW. Semakin banyak coping ekonomi yang dilakukan keluarga mngindikasikan semakin rendahnya kesejahteraan keluarga tersebut. Hal ini terlihat dalam penelitian ini, semua keluarga melakukan coping ekonomi karena keterbatasan ekonomi.

Gejala stres suami pada keluarga TKW cukup rendah, namun pada dimensi fisik termasuk tinggi. Gejala stres suami timbul pasca ditiggal istri bekerja sebagai TKW. Suami mengalami tekanan, terkhusus dalam menjaga anak, memasak dan urusan rumah tangga lainnya. Tekanan-tekanan yang dialami suami menyebabkan suami mengalami gejala stres dan mengakibatkan suami kurang sejahtera dalam menjalani hidup

Besarnya pendapatan istri cukup membantu dalam pemasukan pendapatan keluarga, namun pendapatan istri justru membuat suami tidak sejahtera, berdasarkan pengamatan dan data yang dimiliki peneliti. Hal ini disebabkan oleh penerimaan suami terhadap istri yang harus bekerja sebagai TKW, suami cenderung tidak menerima istri bekerja sebagai TKW, disatu sisi istri sangat berperan dalam membantu kondisi ekonomi, disisi lain suami merasa tertekan karena tidak menerima istri sebagai pencari nafkah dalam keluarga, namun karena keterbatasan suami, dengan terpaksa suami memberangkatkan istri bekerja sebagai TKW.

Banyaknya masalah yang dihadapi suami pasca kepergiaan istri menjadi TKW menyebabkan suami mengalami tekanan fisik dan psikis, seperti mengalami pusing, kurang nafsu makan, selalu berpikir tentang kondisi istri yang merada di negeri orang, tidak bisa tidur, ketakutan yang sangat besar apabila pulang istri bawa anak, sulitnya menyediakan makan dan mencuci pakaian, dan sakitnya mendengar perkataan orang mengenai kurang baiknya suami yang ditinggal istri menjadi TKW. Tuntutan ekonomi, seperti biaya anak sekolah, kebutuhan rumah tangga, dan impiian memiliki rumah yang layak menjadi modal utama istri memberanikan diri berangkat ke negeri orang. Tujuan utama bekerja sebagagi TKWadalah mencapai hidup yang sejahtera, namun pada kenyataanya suami mengalami tekanan dan anaklah yang menjadi korban

\section{DAFTAR ISI}

[BPS] Badan Pusat Statistik. 2016. Data provinsi termiskin 2016. Berita Resmi Statistik [internet]. 4 Januari 2016. [diunduh 2016 September 7]; Tersedia pada: http://www.bps.go.id.

[BPS] Badan Pusat Statistik Jawa Barat. 2016. Garis Kemiskinan Menurut Kabupaten/Kota di Jawa Barat (Rp/kapita/bulan), 2005-2014. Berita Resmi Statistik [internet]. 4 Januari 2016, [diunduh 2016 September 7]; Tersedia pada: http://jabar.bps.go.id.

Alfiasari. 2008. Analisis modal sosial dalam pemberdayaan ekonomi keluarga miskin di Kelurahan Kedung Jaya, Kecamatan Tanah Sareal, Kota Bogor. Vol. 1 no. 1 edisi Januari. Bogor (ID): Institut Pertanian Bogor.

Jurnal Kesejahteraan Keluarga dan Pendidikan (JKKP) Vol.05 No.01 doi.org/10.21009/JKKP.051.03 
Borner, Shively J, Wunder G, Wyman S. 2012. How do rural households respond to economic shocks? Insights from hierarchical analysis using global data. International Association of Agricultural Economists.

Casey L. 2013. Stress and wellbeing in Australia survey 2013. Australian Psychological Society

Carbonell A F. 2005. Income and well-being: an empirical analysis of the comparison income effect. Journal of Public Economics: 89 (2005) 997 - 1019.

Coleman J S. 1988. "Social capital in the creation of human capital." American Journal of Sociology 94 (Supplement): S95-S120.

Celia M, Lenore M. 2004. Somali Women and Well-Being: Social Networks and Social Capital among Immigrant Women in Australia. Human Organization. Vol. 63 :88

Djohan R. 2008. Leader \& Social Capital : Lead to Togetherness. Jakarta: Fund Asia Education

Debebe Z, Mebratie A, Sparrow R, Abebaw D, Dekker M, Alemu G, Bedi A. 2013. Coping with shocks in rural Ethiopia. Working Paper. African Studies Centre.

Dercon S. 2000. Income risk, coping strategies and safety nets. Background paper World Development Report 2000/01: Centre for the Study of African Economies, Oxford University, Department of Economics

Diener E, Tay L. 2013. Rising Income and the Subjective Well-Being of Nations. Journal of Personality and Social Psychology: Vol. 104, No. 2, 267-276 DOI: 10.1037/a0030487

Dwyer A, Cummings A. 2001. Stress, Self-Efficacy, Social Support, and Coping Strategies in University Students. Canadian Journal of Counselling. Vol. 35:3

Ersado L, Alderman H, Alwang J. 2014. Changes in Consumption and Saving Behavior before and after Economic Shocks: Evidence from Zimbabwe. http://www.jstor.org/stable/10.1086/380136

Fujiwara F, Kawachi I. 2008. Social Capital and Health A Study of Adult Twins in the U.S. American Journal of Preventive Medicine. Vol. 35: 2

Garcia M, McDowell T. 2010. Mapping Social Capital: A Critical Contextual Approach For Working with Low-Status Families. Journal of Marital and Family Therapy. Vol. 36 No. 1: 96. 10.1111/j.1752-0606.2009.00188.x

Grootaert C. 1999. Social capital, household walfare and poverty in Indonesia. Working Paper, No.6. Washington DC, USA: The World Bank. Social Development Department.

Hasanah U, Nadiroh, Neolaka A. 2017. The Influence of Couple Interaction, Roles Differences, and Social-Economic Status on Mother's Stress Coping. American Scientific Publisher. Vol. 23 10868 - 10870.

Helliwell J F, Huang H, Wang S. 2013. Social Capital and Well-Being in Times of Crisis. Journal Happiness Study: DOI 10.1007/s10902-013-9441-z

Headey B, Wooden Mark. 2004. The Effects of Wealth and Income on Subjective Well-Being and IIIBeing. Melbourne Institute of Applied and Social Research: IZA DP No. 1032.

Hyyppa M. T, Maki J. (2003). Social participation and health in a community rich in stock of social capital. Health Education Research, 18(6), 770-779.

Hossain S. 2006. Poverty, household strategies, and coping with urban life: examining livelihood framework in Dhaka City, Bangladesh. Bangladesh e-Journal of Sociology, Vol. 2, No. 1.

Jain A K, Giga S I, Cooper C L. 2013. Stress, Health and Well-Being: The Mediating Role of Employee and Organizational Commitment. International Journal of Environmental Research and Public Health: doi:10.3390/ijerph10104907

Jaya, Sumertajaya I M, 2008, Pemodelan persamaan struktural dengan partial least square. Semnas Matematika dan Pendidikan Matematika. Vol. 1118 - 132

Jha R, Nahrajan H K, Pradhan K. 2012. Household Coping Strategies and Welfare: Does Governance Matter? NCAER Working Papers on Decentralisation and Rural Governance in India.

Krantz. 2001. The Sustainable Livelihood Approach to Poverty Reduction. Swedish International Development Cooperation Agency 
Kawachi I. 2006 Commentary: social capital and health: making the connections one step at a time. Int J Epidemiol. Vol. 35:989 -93.

Lazarus, R S, Folkman, S, 1984. Stress, Appraisal, and Coping. New York: Springer.

Mohnen S, Beate V B, Flap H, Subramanian S, Groenewegen P. 2015. The Influence of Social Capital on Individual Health: Is it the Neighbourhood or the Network?. Soc Indic Res. Vol. 121:195-214 DOI 10.1007/s11205-014-0632-8

Markovic, M, Manderson, L. (2002). Crossing national boundaries: Social identity formation among recent immigrant women in Australia from former Yugoslavia. Identity: An International Journal of Theory and Research, 2, 303-316.

Puspitawati H. 2012. Gender dan Keluarga. Bogor (ID): IPB Press.

2013. Ekologi Keluarga: Konsep dan Lingkungan. Bogor (ID): IPB Press.

2013. Pengantar Studi Keluarga. Bogor (ID): IPB Press.

Puspitawati H, Herawati T. 2013. Metode Penelitian Keluarga. Bogor (ID): IPB Press.

Rebecca P, Crnic K A, Cox M J, Mills W R. 2013. The Family Model Stress and Maternal Psychological Symptoms: Mediated Pathways From Economic Hardship to Parenting. Journal of Family Psychology: DOI: 10.1037/a0031112

Rosidah U, Hartoyo, Istiqlaliyah. 2012. Kajian strategi koping dan perilaku investasi anak pada keluarga buruh pemetik melati gambir. Jurnal Ilmu Keluarga dan Konsumen, Vol. 5, No. 1.

Stevenson B, Wolfers J. 2013. Subjective Well-Being and Income: Is There Any Evidence of Satiation? American Economic Review. 103(3): 598-604 http://dx.doi.org/10.1257/aer.103.3.598

Welsh J A, Berry H L. 2009. Social capital and mental health and well-being. National Centre for Epidemiology and Population Health, The Australian National University

Wills E, Orozco L, Forero C, Pardo O, Andonova V. 2011. The relationship between perceptions of insecurity, social capital and subjective well-being: Empirical evidences from areas of rural conflict in Colombia. The Journal of Socio-Economics. Vol. 40 88-96

Yip W, Subramanian S. V, Mitchell A D, Lee D, Wang J, Kawachi I. 2007. Does social capital enhance health and well-being? Evidence from rural China. Journal Social Science \& Medicine: 35 - 49 